ENTREPRENEURSHIP AND SUSTAINABILITY ISSUES

ISSN 2345-0282 (online) http://jssidoi.org/jesi/

2019 Volume 6 Number 4 (June)

http://doi.org/10.9770/jesi.2019.6.4(12)

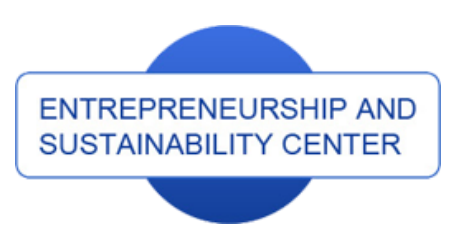

Publisher

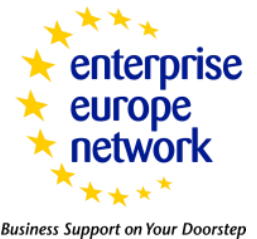

CASPA

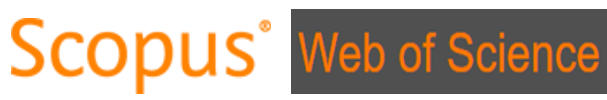

http://jssidoi.org/esc/home

Business Support on Your Doorstep

Clarivate
Analytics

\title{
THE IMPACT OF E-PORTFOLIO USE ON THE DEVELOPMENT OF PROFESSIONAL STANDARDS AND LIFE SKILLS OF STUDENTS: A CASE STUDY
}

\author{
Maha Mohammed Alajmi \\ Curriculum \& Instruction Department, \\ College of Education, Princess NourahBint Abdulrahman University, Riyadh, Saudi Arabia \\ E-mail:mmalajmi@pnu.edu.sa
}

Received 19 January 2019; accepted 10 April 2019; published 30 June 2019

\begin{abstract}
Advancements in Information and Communication Technology (ICT) have transcended barriers and have encompassed almost all aspects of life. It has made valuable contribution to the education sector in general and teacher education in particular. E-portfolio is of great utility and indispensable in the education sector. Its use enables teachers with the opportunity to conveniently return to their experiences and provide the required feedback to the examinee. Using a semiexperimental approach the researcher analyzed the content to prepare the evaluation card for the e-portfolios of student teachers in a prominent University in Saudi Arabia. Amon others, it also addressed the question as to what e-portfolio content is required for the development of professional standards. The findings of the study show that the use of e-portfolios improves capabilities, skills, and knowledge. It also encourages student teachers to know about tendencies, trends, and interests by preparing the file and compiling its contents. A few suggestions arrived from the study is also provided.
\end{abstract}

Keywords: E-portfolion; Life skills; Trainig; Princess Noura; Saudi Arabia

Reference to this paper should be made as follows: Alajmi, M. A. 2019. The impact of E-portfolio use on the development of professional standards and life skills of students in the Faculty of Education at Princess NouraBint Abdul Rahman University, Entrepreneurship and Sustainability Issues 6(4) 1714-1735. http://doi.org/10.9770/jesi.2019.6.4(12)

JEL Classifications: 121,129

Additional disciplines: educology, sociology, psychology

\section{Introduction}

The world has witnessed tremendous development in the field of information and communications technology (ICT) in the preceding and the present century. These developments have transcended barriers and have encompassed almost all aspects of scientific, economic, cultural, and social life; and education sector in general and teacher education in particular is no exception. The use of technologically advanced tools in teacher education programs has become indispensable and justified by the nature and intensity of the overall 


\section{ENTREPRENEURSHIP AND SUSTAINABILITY ISSUES}

ISSN 2345-0282 (online) http://jssidoi.org/jesi/

2019 Volume 6 Number 4 (June)

http://doi.org/10.9770/jesi.2019.6.4(12)

developments in the sector. Technological developments have now been clearly imprinted on the education system in general, and on teacher education programs in particular. It can now be considered as a force to be reckoned with as it has the propensity to affect every aspect of the educational process - both positively and negatively (Sulphey, 2017; Qutait, 2009; Tkacova et al., 2018).

E-portfolio, which is becoming increasingly indispensable in the education sector, can be used to a host of uses like documenting teachers' educational performance, encouraging them to think reflectively, and promoting their professional growth. The use of e-portfolios gives teachers the opportunity to return to their experiences and, thus, provide feedback for the examinee. Though e-portfolios contain the same types of information as their traditional counterparts (paper portfolios); they collect, store, and manage this information electronically. The advantage of e-portfolio is that it requires teachers to be critical with respect to document selection. They are expected to do this based on quality rather than quantity. To develop their performance, teachers should adopt contemplative thinking methods that reflect their own views, based on their experiences (Constantine and Lorenzo, 2004). According to Gordon (2009) the use of e-portfolios enables teachers and supervisors to follow up on their students' work; on the basis of predefined criteria that enable the evaluation and feedback of completed reports, assignments, and other activities or materials.

In addition to providing tools for professional empowerment, e-portfolio encourages teachers to assume very high levels of responsibility (Constantine and Lorenzo, 2004). The platform for discussions presented by e-portfolio provides learners with an opportunity to obtain feedback. Since all the records of their performance and development are maintained, it enables teachers to learn and grow as professionals through a form of cooperative mentality. Enrichment of an e-portfolio is possible by including more relevant information related to educational objectives. This information can be presented in various forms, such as animations, simulations, television images, multimedia projects, and presentations. The file attachments can be stored on CD-ROMs, as well as on an electronic index, which helps the evaluator identify the sections in which he or she is most interested. Visually checking and reviewing these sections does not require one to browse through pages (Al-Massaad, 2012).

Professional standards are required to mould future teachers and to make them perform skillfully, quickly, and masterfully. All these skill sets are intertwined, and they contribute towards performance of specific professional activities that could involve planning standards, lesson implementation, teaching aids, classroom management, and assessment (Abu Sawawin, 2010). Several studies have emphasized the importance of preparing students on the basis of professional standards. This can be done through field training programs that serve as a tool of educational experience and prepare students for the teaching profession (Mulla, 2004).

Further, it is indispensable for the students to have the required skills to address the challenges and difficulties they encounter in their lives in accordance with their beliefs and preferences (Aga, 2012; Sulphey and Al Kahtani, 2017). Acquiring of these life skills has to be an important product of the curriculum at all levels of education. This should not be limited to a particular subject, and is the joint responsibility of all teachers that can in no way be exempted from any specialization. Life skill would help students develop social skills and enable them to live and deal appropriately with different people and circumstances (Ayad and Saad al-Din, 2010). Nasr (2011) stresses that students' mastery of life skills creates an opportunity for them to excel in life. She proposed training students in skills and practices by following an evidence-based approach that could enable the identification of actual student needs, as well as the potential pressures and challenges they face. Ayad and Saaduddin (2010) classified life skills into three main categories:

- Basic life skills, including in communication, writing, and reading

- Analytical life skills, including in problem-solving, information research, and technology use

- Effective skills, including in conflict management, citizenship, and career development 


\section{ENTREPRENEURSHIP AND SUSTAINABILITY ISSUES}

ISSN 2345-0282 (online) http://jssidoi.org/jesi/

2019 Volume 6 Number 4 (June)

http://doi.org/10.9770/jesi.2019.6.4(12)

Presently e-portfolios are used by numerous universities, colleges, and schools in the United States as a tool for evaluating teaching learning process. Now based on the stipulations of the National Board for Professional Teaching Standards, it has become a key element. The American Association of Higher Education has stipulated that e-portfolios must be used as a tool to improve teaching in colleges and universities. Further, the use of eportfolios has become one of the conditions for obtaining a license to practice teaching (Qutait, 2009).

Recently Saudi Arabia has been focusing on strategies towards enhancing the quality of higher education (Sulphey and Al-Kahtani, 2018; Sulphey, AlKahtani and Syed, 2018). The Government has been allocating substantial sums towards this too. Princess Noura Bint Abdul Rahman University is a premier Institution in Saudi Arabia with state-of-art facilities. The College of Education at the University is keen to provide students with advanced ICT skills. However, these skills fail to enable them to design and utilize their own e-portfolios. Today, paper portfolios are being used by students due to various reasons. Some of them include low student awareness levels regarding the design, production, and benefits of e-portfolios. This issue made the researcher to examine need of recognizing the association of using e-portfolio for the development of professional standards and life skills among the students. The present study is conducted at the Faculty of Education at Princess Noura Bint Abdul Rahman University, Saudi Arabia.

\section{Review of literature}

The theoretical framework for this study addresses several issues related to the subject of the research. The literature review begins with a brief background of the transition from paper-based portfolios to e-portfolios, summarizing the incorporation of the latter into higher education as a tool for program evaluation and assessment. It also considers its value in developing the professional standards and life skills of student teachers.

\section{e-Portfolios - from Paper to Electronics}

Student-developed portfolios were first introduced in the 1960s. Prior to this portfolio was used by artists and designers to gather and present their work. Portfolios were popular until the early 1990s because of the widespread belief in their effectiveness within the liberal education movement, which made conservative means of authentic evaluation (Fenwick \& Parsons, 2009). The National Learning Infrastructure Initiative provided the following definition of an e-portfolio:

A collection of authentic and diverse evidence, drawn from a larger archive representing what a person or organization has learned over time, on which the person or organization has reflected, and that is designed for presentation to one or more audiences for a particular rhetorical purpose. (Barrett, 2007, p. 438)

The use of portfolios for educators is defined as:

"A purposeful collection of student work that exhibits the student's efforts, progress, and achievements in one or more areas. The collection must include student participation in selecting contents, the criteria for election, the criteria for judging merit, and evidence of student selfreflection." (Paulson, Paulson, and Meyer, 1991: 60)

According to Barrett (2007) portfolios have several labels like documentary bag, student work file, learning file, achievement file, learning bag, performance file, and growing records. They could be paper contents (documentaries), videos, and audio tapes, as well as pictures from magazines, newspapers, and paper texts. She added that achievement files can take numerous forms like paper portfolios and e-portfolios $(\mathrm{CD}$, Web and Web + $\mathrm{CD}$ ).In higher education institutions, e-portfolios have become a popular "tool to enhance learning, conduct assessment, meet standards, and increase student employability" (Chatham,et al., 2009: 438). 


\section{ENTREPRENEURSHIP AND SUSTAINABILITY ISSUES}

ISSN 2345-0282 (online) http://jssidoi.org/jesi/

2019 Volume 6 Number 4 (June)

http://doi.org/10.9770/jesi.2019.6.4(12)

\section{The Role of e-Portfolios}

Studies by Abrinca (2007) and Barrett (2007) found that the e-portfolio differs from the paper portfolio in numerous ways. It also has a number of advantages. E-portfolios, for example, are able to integrate more than one technological medium like presentations, videos, fixed or mobile images, and/or written text. The following are additional advantages of the e-portfolio:

- Easy storage.

- High storage capacity using minimal space.

- Easy construction and control.

- Minimal time and effort.

- Development of teachers' and students' technological skills.

Chatham, et al. (2009) stated four goals of e-portfolios: to facilitate reflective learning, showcase career skills, showcase professional standards, and assist with program review and assessment.

\section{Benefits of e-portfolio in field training}

The electronic achievement file has a number of benefits (Mazen, 2009), which are now be reviewed.

1. Enhancement of self-assessment and reflection: The e-portfolio enhances the development of selfassessment and contemplative thinking (Barton, Collins, Barton, and Collins, 1993). The practical initiation of the e-portfolio requires the teacher to determine facts or educational events, analyze occurrences, and assess students' educational performance and learning outcomes (O'Leary, 2008).Eportfolios can take the form of video and audio recordings. For teachers, this provides a true picture of their performance in the classroom, thereby giving them the opportunity to reflect on and analyze educational experiences and events, which can ultimately promote self-assessment and reflective thinking.

2. Achievement of personal satisfaction and reflecting innovation: The e-portfolio is the result of the owner's efforts. It is the purposeful collection of his or her best work during a certain period, and it demonstrates the progress in different areas, thereby giving a sense of satisfaction and self-confidence. It can be considered as a mirror that reflects the personality of the owner, as well as the extent of his or her progress and development (Gartner, 2011).

3. Provision of tools for professional empowerment: E-portfolios can be a source of power and empowerment, as they encourage teachers to carry greater responsibilities, which enables them to learn and grow professionally. Additionally, during the course of their service, it helps them to set their goals and their plans for continuous professional growth, as opposed to relying on an administrator to determine the efficiency of their professional development through one or two evaluation processes conducted throughout the year. According to Andreson and DeMuelle (1998), pre-service teachers who use achievement files are more informed about topics related to the difficulties of a profession in education. They are better capable of conducting self-evaluation, and better understand the importance of continuing professional development.

Teaching is not defined solely by number of courses taught; but also by the various and varied experiences, research, workshops, and other educational activities that contribute to teachers' growth. Mentors are responsible for integrating the knowledge, attitudes, and skills that they have learned through these experiences and documenting them in their professional files; thereby giving them considerable power to build their selfconfidence as new teachers. 


\section{ENTREPRENEURSHIP AND SUSTAINABILITY ISSUES}

ISSN 2345-0282 (online) http://jssidoi.org/jesi/

2019 Volume 6 Number 4 (June)

http://doi.org/10.9770/jesi.2019.6.4(12)

\section{Achieving scientific cooperation}

The achievement file is a method of evaluating educational performance, and it gives the teacher opportunities to participate in collaborative discussions with the evaluator, through regular feedback and guidance. The collaborative approach to building personal experiences to support self-reflection and improve teaching skills leads to the common goal of sustained professional growth (Gartner, 2011). The use of e-portfolios facilitates Internet file sharing and, therefore, the potential to receive feedback not only through but also beyond the supervisor, such as other external supervisors, peers, mentors, cooperating teachers, and parents.

\section{Integrated curves in the evaluation of practical training programs}

The completion of an e-portfolio provides evidence of performance through demonstration and the use of multiple sources of information, which is impossible to achieve using traditional evaluation forms. Thee-portfolio is, therefore, a more reliable tool for evaluating teachers' learning and growth (Lowendahl, 2011). E-portfolios are important tools, as they add more life and depth to traditional evaluation methods. The items included in an eportfolio are original study plans; evidence of students' learning through written feedback from classroom observation; and culturally and socially based inputs. These provide a holistic view of the achievement of each individual, compared to relying solely on his or her overall grades, examination results, and curriculum vitae.

\section{Criticism of e-portfolios}

e-portfolios have been criticized by a number of researchers. It is opined that in theory, e-portfolios were believed to be beneficial for learning. However, in practice, they were noted to cause confusion and disappointment (Chau and Cheng, 2010). Deneen and Shroff (2010) discussed whether the benefits of e-portfolio use outweigh the costs of acquiring the required ICT literacy (time, money, and patience). Their conclusions were positive but included significant cautions regarding technology challenges that may be addressed through time, structure, and diligent effort. According to Al Masad (2012), administrators expressed concerns regarding the potentially excessive amount of time required for the use of e-portfolios as assessment tools. Additionally, Al - Omari (2013) warned that the effective application of e-portfolios required significant awareness of processes and workflows.

\section{Criteria for success}

Extensive research and numerous case studies have addressed the effective application of e-portfolios. The recommendations are provided in various areas, such as stakeholder administration, faculty and student commitment, program organization, mentoring and practicing, and ICT literacy. Barrett (2007) stated that the teacher's position is critical to success, and high-accomplishing teachers (as judged by student commitment) effectively used reflection, awareness, and other learning strategies to provide students with detailed feedback. Overall, ICT strategies and skills, support systems, and cooperators were also important components of high levels of student commitment. Deneen and Shroff (2010) discussed the importance of ICT literacy and innovative educational programs in effective e-portfolio application.

To improve reflective learning, Winsor, et al (1999) suggested the utilization of a sophisticated model using inquiry as the primary means of guiding the student during the portfolio process, thereby leading to high-quality reflective learning. Tindall-Ford, Waters, and Johnson (2010) explained various requirements, which included thorough planning by staff and students; e-portfolio assignments planned from the basics, as opposed to proceeded as using preset assignments. Certain others include the demand for key stakeholders to accept the standard and function of the e-portfolio system; the use of recommended training and outstanding assistance; an affirmative and supportive culture; and the availability of the e-portfolio to enable the student access after graduation.

Al Masad (2012) stressed the significance of early agreement on the objectives of evaluation and the need to encourage collaboration among administrators, faculty, consultants, and program reviewers. Hallam and Creagh 


\section{ENTREPRENEURSHIP AND SUSTAINABILITY ISSUES}

ISSN 2345-0282 (online) http://jssidoi.org/jesi/

2019 Volume 6 Number 4 (June)

http://doi.org/10.9770/jesi.2019.6.4(12)

(2010) pointed out that open discussion and cooperation among stakeholders is crucial. According to Granberg (2010), it is necessary to cope with the stress between using e-portfolios for summative evaluation versus for outstanding reflection and learning. Buckley, Coleman \& Khan (2010) stated that an e-portfolio program should allow for the following: rational time requests; assistance with improving one's reflective skills; portfolios preparation that reflects training demands; specific goals and objectives; consistency with regard to course outcomes; and obvious guidelines governing requirements, word count, and time involvement. The program should also be implemented with an extensive amount of time to enable the promotion of reflective skills.

According to Al Masad (2012), there is a predilection for fulfilling e-portfolios using a bottom-up rather than a top-down approach. They also discussed the need for a considerable amount of administrative assistance for faculty and students, organized technical help, and need for the faculty members participating in e-portfolio's need to broaden their vision. Winsor et al. (1999) advised that the program should be designed to guarantee constant access to the e-portfolio and sufficient ICT and process training for both students and faculty.

\section{Professional standards}

Teachers have received great attention through the existing teacher training programs on professional standards. According to Al-Fatawi (2003):

"[these] programs ... set precise targets for teacher training, the required professional standards are clearly defined, [and] teachers are then required to take responsibility for these levels: Their trainers shall be responsible for ensuring that the specified objectives are met" (Al-Fatalawi, 2003: 32).

Makhlafi (2004) pointed to the need to focus on collective assessment and feedback during the training of student teachers in skills and professional standards, and ALkatabi (2004) explained the need to provide lists of professional competencies that contribute to the achievement of teachers' standards, which represent the aspirations of pre-and in-service teachers. Abu Sawawin (2010) underscored the need to prepare the student teacher using a variety of methods during practice.

\section{The relationship between education based on professional standards and teacher education programs}

The first appearance of lists of professional standards in teacher training programs is through what Dodle (1973) did, which indicated that the first to use these lists is Kinney in 1952 through his collaboration with the California Council for Teacher Preparation so as to follow up and evaluate the performance of teachers in the general education stages. The lists of professional standards for teacher education programs have undergone a number of modifications. Since their inception in the 1960s, there has been a shift in teacher education programs, from competency-based to standards-based. This trend spread across the USA and was adopted by numerous colleges and teacher preparation institutions. It has been supported by extensive empirical research, including studies by Stanford (1976), Young and Young (1969), and Oaillems (1977). These studies focused on the importance of this trend in the development of desirable professional standards for teacher performance (Jamea, 1984: 67).

Jamea (1984) explained that education based on professional standards is unique in regard to a number of features. Adherence to a systematic plan for setting standards and developing training programs entails the following:

- Students' speed of learning and growth criteria are evident in their behavior

- The development of teachers' special abilities and standards leads to the reflection of their knowledge acquisition

- Approaching the teacher as often as possible regarding fieldwork requirements related to academic level, skills, and performance 


\section{ENTREPRENEURSHIP AND SUSTAINABILITY ISSUES}

ISSN 2345-0282 (online) http://jssidoi.org/jesi/

2019 Volume 6 Number 4 (June)

http://doi.org/10.9770/jesi.2019.6.4(12)

- Focus on numerous current educational and psychological trends in the fields of education and psychology, such as self-education.

- Attention to trends in the field of education technology

- Use of different types of evaluation: diagnostic, intertribal, and structural

\section{The preparation of the teacher in light of the professional standards concept}

Preparation of the teacher based on professional standards is one of the most important modern trends in the field of education and the tremendous developments regarding the use of computers and the Internet. Their vision of teacher training programs enables the mastery of new professional standards before engaging in actual work. Abdul-Samie and Hawala (2005) pointed out that in light of professional standards, preparing the teacher entails the following:

- Determining the required parameters of the teacher in the setup program.

- Training him or her on performance and practice that is contrary to what is done in preparation programs that are based on theoretical knowledge

- Including learning experience in the preparation program in the form of specific criteria that helps the teacher to perform his or her new educational roles.

- Ensuring that the preparation program meets the standards according to which the qualifications of the teacher will be assessed

\section{The philosophy of teacher preparation based on professional standards and characteristics}

This can be summed up in five points:

1. The program has to be based on determining and outlining in a clear and precise manner the criteria that teachers need to meet, thereby making the student teacher more sensitive to their importance and more aware of their meaning to him or her.

2. It has to help the student teacher to see his or her progress and rely on observation and senses in light of the criteria for accurate and acceptable performance levels.

3. It should focus on the student teacher, as the supervisor is more interested in individual standards for each student teacher and is keener to provide opportunities for him or her to demonstrate in future behavior.

4. It offers training programs, processes, and evaluation that are clear, specific, and effective.

5. It develops the idea of enhancing training and providing the teacher with numerous opportunities to achieve competencies that are determined using the various means and methods available in the training activities. (Al-Khamisi, 2003)

Based on the foregone discussion it is clear that the professional standards that are determined are expected to be conveyed to the student teachers and that their awareness of these standards should help them to do their jobs more effectively and continuously improve their performance.

\section{Classification of the current professional standards}

Based on the objective of the current study - to measure professional standards for student teachers; and in light of the above theoretical classifications, it is proposed that professional standards should also be classified as follows:

- Planning standards

- Classroom management standards

- The use of teaching aids standards

- Standards of teaching methods

- Evaluation standards 


\section{ENTREPRENEURSHIP AND SUSTAINABILITY ISSUES}

ISSN 2345-0282 (online) http://jssidoi.org/jesi/

2019 Volume 6 Number 4 (June)

http://doi.org/10.9770/jesi.2019.6.4(12)

Researchers, such as Abdullah (2007) and AbuSwain (2010), emphasized the importance of adequate planning and the need for teachers to achieve success in the profession, as this clarifies other teachers' understanding of the objectives of education and reduces the randomness of teaching. The following are additional benefits of this emphasis:

1. It gives teachers the opportunity to review material and enhance their development by reading other sources, especially as a result of the explosion of technological knowledge, which has provided required resources that can be utilized, including through Internet networks and the various available search engines.

2. Preplanning lessons gives teachers an opportunity to choose the appropriate interaction method for the nature of the subject and the lesson.

3. Preplanning lessons gives teachers an opportunity to refine and classify the material and makes it easier for students to benefit from it.

4. It enables the achievement of set objectives within a specific time frame.

5. It makes lesson scholarly and allows for the determination of whether it has been achieved to a sufficient degree.

6. Preplanning lessons gives teachers an opportunity to prepare thought-provoking, critical, and creative questions.

According to Dahlan (20108), classroom management is important for the following reasons:

1. It provides an emotional and social climate that is conducive to learning.

2. It organizes the physical and psychological environment, ensuring its suitability for learning.

3. It provides, organizes, and directs educational experiences.

4. It enables the observation of students, follow-up on their progress, and evaluation

Classroom management is an art and a science, and it relates to the teacher's style in dealing with students both inside and outside the classroom; as well as the management of the class itself, its laws, and its procedures. The use of the Internet helps to illustrate the differing experiences of teachers of different nationalities in regard to active classroom management, and this can lead to an improvement in the teacher's performance in this regard.

It is essential that educational techniques be closely linked to the curriculum and integrated with it so that it becomes one of its basic components. ALhila (2002) believes that modern technical and technological developments have contributed to the trend of using educational techniques in general. In today's world, this is now known as the technology of education, whereby the openness of the world as a result of the use of the Internet helps to diversify educational techniques, which improve the educational process. This helps in selecting appropriate educational tools that meet the needs of learners and allow for the achievement of lesson objectives in less time and with less effort than would be the case in a world without the Internet.

Modern teaching methods vary according to the changing outlook on the nature of the education process. This outlook is dependent on conservation and amplification of knowledge and has expanded to include cognitive levels which require positive thinking on the part of the learner. The aim is to demonstrate the potential of the students and increase their potential. Traditional teaching methods are no longer suited to contemporary life. Therefore, numerous educational theories have emerged with a view to helping students' teachers to acquire many mental, social, and motor skills. The modern-day teacher's task involves providing learners with the opportunity to acquire knowledge themselves, to participate effectively in all educational activities, and to develop the skills of independent thought and self-reliance when it comes to their work.

Dahlan (2010) stated that evaluation standards are the total number of actions performed by the teacher before, during, and after the teaching process. These standards are intended to enable them to obtain quantitative data 


\section{ENTREPRENEURSHIP AND SUSTAINABILITY ISSUES}

ISSN 2345-0282 (online) http://jssidoi.org/jesi/

2019 Volume 6 Number 4 (June)

http://doi.org/10.9770/jesi.2019.6.4(12)

regarding learning outcomes to enable them to assess changes in student behavior using a toolkit (verbal and written questions or the observation of specific behavior). The evaluation in education is defined as:

"a judgment on the success of the educational process to achieve the overall objectives it contains, as well as [to] promote students' strengths and treat his weaknesses" (Dahlan, 2010: 152).

Consequently, it is important for the student teacher to search and explore every aspect that serves the educational process, including new innovations used in the field of evaluation, especially in light of the tremendous acceleration of technology and the development of evaluation competencies.

\section{Life skills}

The acquisition of life skills is one of the important and desired learning outcomes based on a structured approach. Lessons about life skills are offered to learners at any stage of the educational process and are not limited to any particular subject. Life skills relate to common responsibilities that cannot be exempted from any specialization, and reference to this aspect of education is in essence concerned with the matter of the individual's acquisition of talent, attitudes, values, and skills. They enable the individual to live with diverse people and interact with them socially in a way that leads to adaptation and the ability to work, and to participate in the process of economic, social, and political development of the individual him or herself (Greene, 2008; Hassan, 2009).

It should be noted here that many educational institutions have been defined life skills as, cognitive, social, personal, and psychological skills related to students' handling of requirements and challenges in their daily lives. These skills vary according to different cultures, environments, circumstances, and themes, and they include decision-making, problem-solving, communication, negotiation, creative thinking, critical thinking, selfawareness, empathy, resistance to stress, planning for the future, self-assertion, discord, and listening (World Health Organization, 2003).

\section{Characteristics of life skills}

Every community needs a variety of skills necessary for the individual living within it, and the quality of the skills differs for each society, according to its growth, and development. There may be similarities in terms of some general life skills that individuals are required to have. These may include skills related to decision-making and problem-solving, which can be agreed upon at all times and in all places. However, the nature and quality of the decisions and the problems facing the individual in society vary. In addition, the life skills required by individuals in society vary from one time period to another, depending on the stage of development of the society. Therefore, it cannot be determined that there are life skill characteristics that are suitable for all societies, but scientific frameworks and foundations can be developed, and based on these (Danish and Steven, 2000).

The following are the characteristics of life skills (Holt et al., 2008):

1. They vary and include both physical and intangible aspects associated with the methods of satisfying the individual's needs and his or her requirements for interaction with life.

2. They depend on the nature of the relationship between the individual and society and their impact on each other.

3. Their aim is to help the individual to successfully interact with other people, and to develop coping methods to deal with regular daily life situations, as well as new ones that might develop.

This also include the ability to solve personal or social problems, face daily challenges, make adjustments and improvements in the style and quality of one's life as an individual and a member of society. In addition it should also include measuring the strengths and weaknesses with regard to the life skills of the individual by assessing 


\section{ENTREPRENEURSHIP AND SUSTAINABILITY ISSUES}

ISSN 2345-0282 (online) http://jssidoi.org/jesi/

2019 Volume 6 Number 4 (June)

http://doi.org/10.9770/jesi.2019.6.4(12)

the strengths and weaknesses of his or her choices. The life skills are strong if the person is able to do all the things in the aforementioned list, and whenever his or her choices are poor, this is a reflection of his or her poor life skills.

It is clear from the above that life skills consist of cognitive components of how behavioral decisions are made. The emotional components that drive the choice of behavioral style and the technical components are represented in the manner in which the individual implements his or her skills. Accordingly, the researcher defines procedural life skills as mental, emotional, and sensory abilities, which enable the individual to solve problems, face the challenges of daily life, and make adjustments to individual and community lifestyles.

Factors influencing the individual's acquisition of life skills

A few factors that influence an individual's acquisition of the required life skills are presented here:

- Subsidized relationships: The presence of support of family and friends for skill acquisition. In the absence of these relationships of support, the individual tends to neglect the skill, while the presence of this support positively affects the learning of the skill.

- Models: The individual should note the models to implement the skill and should practice, simulate, and imitate them.

- Reward sequence: Receiving encouragement and praise and being shown compassion is basic rewards in the formation of a life skill.

- Instruction: Most life skills instruction is obtained from home, school, and university. There are instructions for how to study and maintain one's health, and these must be followed closely at home school and university.

- Opportunity: Dependence on others makes it difficult for students to acquire life skills, as they need opportunities to practice them independently.

- Interaction with others: Learning skills from colleagues and the surrounding environment may be helpful or harmful, depending on the nature of the skills and the colleagues.

\section{Life skills classification}

There is no standardized classification of life skills. These skills are determined based on knowledge of students' needs and aspirations, as well as the problems that arise when students lack these skills. Students will be expected to learn skills from others and to go back to the models and instruction for life skill acquisition, as determined by specialists. Al-Omari (2013) states that life skills are classified as follows:

- Communication and interpersonal skills, including verbal and nonverbal communication, as well as the ability to listen, express one's feelings, and make observations

- Negotiation and rejection skills, including conflict management, confirmation skills, and rejectionist skills

- Emotional skills (emotional understanding and empathy), including the ability to listen to the needs and circumstances of others while understanding and expressing this understanding

- Collaboration and teamwork skills, including expressing respect, and assessing another person's abilities and his or her contribution to the group

- Advocacy skills, including persuasion, motivation, decision-making, and thinking abilities.

- Information-gathering skills, including the ability to assess future results, identify alternative solutions to problems, and analyze skills related to the impact of the values, self-orientation, and attitudes of others being able to do all these when there is stimulus.

- Critical thinking skills, including interpersonal skills analysis; interpersonal skills; the ability to analyze trends, values, social norms, and beliefs; the ability to identify sources of information; interpersonal skills; and self-management 


\section{ENTREPRENEURSHIP AND SUSTAINABILITY ISSUES}

ISSN 2345-0282 (online) http://jssidoi.org/jesi/

2019 Volume 6 Number 4 (June)

http://doi.org/10.9770/jesi.2019.6.4(12)

- Skills to increase the focus of the inner mind of the child, including self-esteem and interpersonal skills, as well as self-awareness, goal setting, and self-assessment skills.

- Emotional management skills, including interpersonal skills related to grief and anxiety; and skills to deal with loss, trauma, and abuse

- Stress management skills, including those related to time management, positive thinking, and relaxation

The individuals' choice of life skills will vary, and focus depends on the individual and local conditions. Ultimately, it is the interaction of skills that produces great behavioral outputs. The need to pay attention to life skills and to provide every learner with them can be difficult due to the modern changes and challenges of this era, as well as the learner's academic performance of the work required of the learner. These skills enable the achievement of successful coexistence, adaptation, flexibility, and success in both the personal and the professional areas of one's life.

\section{Methodoly}

The researcher will use the descriptive method of analyzing the content to prepare the evaluation card for the eportfolios of student teachers. The researcher followed the semi-experimental approach. This involves making a change to the independent variable and observing what happens to the dependent variables. This study seeks to answer the following questions:

1. What e-portfolio content is required for the development of professional standards for student teachers in the College of Education at Princess Noura Bint Abdul Rahman University?

2. What is the level of mastery required for student teachers in the College of Education at Princess Noura Bint Abdul Rahman University to be able to use e-portfolios?

3. What is the effect of the use of e-portfolios on the development of professional standards for student teachers in the College of Education at Princess Noura Bint Abdul Rahman University?

4. What is the effect of using e-portfolios on the life skills development of student teachers in the College of Education at Princess Noura Bint Abdul Rahman University?

5. Are there any statistically significant differences between the average pre- and post-application student teachers in the College of Education at Princess Noura Bint Abdul Rahman University based on the checklist of professional standards?

6. Are there any statistically significant differences between the average pre- and post-application student teachers in the College of Education at Princess Noura Bint Abdul Rahman University in terms of the life skills scale?

\section{Study community}

The study community will consist of all senior students specializing in primary education (110) enrolled in the Field Training in Primary School course in the first semester of the 2018/2019 school year.

\section{The study sample}

The simple randomized method will be used to extract a representative sample of the study population that is 35 senior students specializing in primary education and enrolled in the Field Training in Primary School course in the College of Education.

\section{Study tools}

To achieve the objectives of the study, the study tools comprised the following:

1. Checklist of professional standards

2. E-portfolio evaluation cards (checklists) 
ENTREPRENEURSHIP AND SUSTAINABILITY ISSUES

ISSN 2345-0282 (online) http://jssidoi.org/jesi/

2019 Volume 6 Number 4 (June)

http://doi.org/10.9770/jesi.2019.6.4(12)

3. Life skills scale

Checklist of professional standards

The researcher has formulated a checklist of professional standards by studying the literature on education and reviewing previous research related to the problem of studying. In addition to this they should have benefited significantly from the assessment cards reflecting the primary grades of the student teachers in the Faculty of Education at Princess Noura Bint Abdul Rahman University. Some of the evaluation cards of students enrolled at other Saudi universities were also viewed.

The list of professional standards was prepared based on five areas: planning (12 standards), classroom management ( 6 criteria), use of teaching methods ( 7 standards), use of teaching aids ( 7 standards), and assessment (8 standards).

\section{Tool validation}

The checklist of professional standards was presented to a number of arbitrators, who were asked to express their views on the clarity of each paragraph. The arbitrators made important observations, based on which the researcher made the necessary amendments. Accordingly, the paragraphs (37) that were agreed upon by the arbitrators were chosen for their validity.

\section{Internal consistency}

The final checklist of professional standards was estimated by calculating the Cronbach's alpha coefficient. Based on the aforementioned, the professional standards are characterized by a high degree of honesty and consistency.

\section{E-portfolio evaluation card (checklist) Building checklists}

The researcher relied on previous studies of portfolios as the main source from which to derive the primary objectives that will be achieved. The literature in this field emphasized three purposes: gathering experiences, selecting the best portfolios, and enabling growth by identifying weaknesses and strengths.

\section{Tool validation}

The checklists were presented to a group of faculty members and educational supervisors. After the researcher reviewed the notes, the amendments were made; these were limited to clarifying the meaning of some paragraphs.

\section{Stability through the use of other analysts}

Three e-portfolios were analyzed and evaluated by the researcher and two colleagues. The stability of the portfolios was calculated using the holistic equation, which shows that the ratio of the agreement between the researchers with the two analysts was 95.4.

\section{Life skills scale}

The questionnaire consisted of 37 words divided into four dimensions that address the most important life skills of the teacher (interpersonal, decision-making, problem-solving, and academic).

\section{Tool validation}

The scale was presented to a number of arbitrators, who were asked to express their views on the clarity of each paragraph. The arbitrators made important observations, based on which the researcher made the necessary amendments. The paragraphs (37) agreed upon by the arbitrators were chosen.

\section{Stability of the tool}

The researcher used the Cronbach's alpha method to determine a invariable coefficient, which was higher at 0.793. This indicates that the questionnaire has a high degree of stability. 
ENTREPRENEURSHIP AND SUSTAINABILITY ISSUES

ISSN 2345-0282 (online) http://jssidoi.org/jesi/

2019 Volume 6 Number 4 (June)

http://doi.org/10.9770/jesi.2019.6.4(12)

\section{Statistical methods}

The researcher used a number of statistical methods like percentages, arithmetic mean, Cronbach's alpha, t-tests, and ETA square $\eta 2 \mathrm{c}$.

\section{Results}

\section{Results of the first question}

"What e-portfolio content is required for the development of professional standards for student teachers in the College of Education at Princess Noura Bint Abdul Rahman University?"

To answer this question, the researcher examined previous studies of e-portfolios, in addition to a list of the contents of the files and paper portfolios of student teachers enrolled in other Saudi universities. Additionally, the researcher benefited from the websites of some Arab and foreign universities interested in using e-portfolios for student teachers.

\section{Results of the second question}

"What is the level of mastery required for student teachers in the College of Education at Princess Noura Bint Abdul Rahman University to be able to use e-portfolios?" To answer this question, the researcher used a t-test for one group to compare the average score of the student teachers based on the assessment of the e-portfolios according to the checklists (teaching experiences, best work, strengths, and weaknesses) in the selected value (degree of mastery equaling $75 \%$, as identified by an experienced consultant) and so on, as shown in the Table 1:

Table 1. T-test for one group to compare the average students' scores (sample)

E-portfolio score card for the compilation of experience (selected value: $75 \%$ )

\begin{tabular}{|c|c|c|c|c|c|c|}
\hline Checks & $\begin{array}{c}\text { Arithmetic } \\
\text { mean }\end{array}$ & $\begin{array}{l}\text { Standard } \\
\text { deviation }\end{array}$ & $\begin{array}{l}\text { average percentage } \\
\text { (default) }\end{array}$ & $\begin{array}{l}\text { average percentage } \\
\text { (actual) }\end{array}$ & $\mathrm{T}$ value & Significance level \\
\hline Introduction & 5 & 0 & $75 \%$ & $100 \%$ & 0 & 0 \\
\hline $\begin{array}{l}\text { Field of } \\
\text { planning }\end{array}$ & 4.7 & 0.19 & $75 \%$ & $94 \%$ & 120.5 & $\begin{array}{l}\text { Function statistically } \\
\text { at } 0.01\end{array}$ \\
\hline $\begin{array}{l}\text { Scope of } \\
\text { classroom } \\
\text { management }\end{array}$ & 3.8 & 0.72 & $75 \%$ & $75.8 \%$ & 23 & $\begin{array}{l}\text { Function statistically } \\
\text { at } 0.01\end{array}$ \\
\hline $\begin{array}{l}\text { Scope of use of } \\
\text { teaching } \\
\text { methods }\end{array}$ & 3.9 & 0.89 & $75 \%$ & $77 \%$ & 17.28 & $\begin{array}{l}\text { Function statistically } \\
\text { at } 0.01\end{array}$ \\
\hline $\begin{array}{l}\text { Scope of use } \\
\text { of teaching aids }\end{array}$ & 4.5 & 0.64 & $75 \%$ & $92 \%$ & 38.91 & $\begin{array}{l}\text { Function statistically } \\
\text { at } 0.01\end{array}$ \\
\hline $\begin{array}{l}\text { Scope of } \\
\text { evaluation }\end{array}$ & 3.8 & 0.46 & $75 \%$ & $76 \%$ & 36.5 & $\begin{array}{l}\text { Function statistically } \\
\text { at } 0.01\end{array}$ \\
\hline Total grade & 4.3 & 0.39 & $75 \%$ & $85.9 \%$ & 49.5 & $\begin{array}{l}\text { Function statistically } \\
\text { at } 0.01\end{array}$ \\
\hline
\end{tabular}

It is clear from the table above that significant differences exist in the average grades of the student teachers (sample study) based on the e-portfolio assessment cards for the compilation of experience (selected value: 75\%), as all the relative weights of the actual mean are above the default percentage. This is because of the student teachers' awareness of the parameters for the e-portfolios and their importance, the steps to be prepared, the criteria to be assessed, and the feedback they will receive. This information was obtained while the researcher and her peers viewed and discussed the files, which displayed some examples of e-portfolios. 
ENTREPRENEURSHIP AND SUSTAINABILITY ISSUES

ISSN 2345-0282 (online) http://jssidoi.org/jesi/

2019 Volume 6 Number 4 (June)

http://doi.org/10.9770/jesi.2019.6.4(12)

Table 2. T-test for one group to compare the average student teachers' scores (sample)

E-portfolio score card for the best work (checklist and selected value: $75 \%$ )

\begin{tabular}{|l|c|c|c|c|c|l|}
\hline Checks & $\begin{array}{l}\text { Arithmetic } \\
\text { mean }\end{array}$ & $\begin{array}{l}\text { Standard } \\
\text { deviation } \\
\text { (default) }\end{array}$ & $\begin{array}{l}\text { average percentage } \\
\text { average percentage } \\
\text { (actual) }\end{array}$ & T value & Significance level \\
\hline $\begin{array}{l}\text { Field of } \\
\text { planning }\end{array}$ & 4.3 & 0.18 & $75 \%$ & $88 \%$ & 29.5 & $\begin{array}{l}\text { Function statistically } \\
\text { at } 0.01\end{array}$ \\
\hline $\begin{array}{l}\text { Scope of } \\
\text { classroom } \\
\text { management }\end{array}$ & 4.8 & 0.62 & $75 \%$ & $\begin{array}{l}\text { Function statistically } \\
\text { at } 0.01\end{array}$ \\
\hline $\begin{array}{l}\text { Scope of use of } \\
\text { teaching } \\
\text { methods }\end{array}$ & 3.9 & 0.89 & $75 \%$ & $87 \%$ & 31.28 & $\begin{array}{l}\text { Function statistically } \\
\text { at } 0.01\end{array}$ \\
\hline $\begin{array}{l}\text { Scope of use of } \\
\text { teaching aids }\end{array}$ & 3.5 & 0.84 & $75 \%$ & $86 \%$ & 32.91 & $\begin{array}{l}\text { Function statistically } \\
\text { at } 0.01\end{array}$ \\
\hline $\begin{array}{l}\text { Scope of } \\
\text { evaluation }\end{array}$ & 3.8 & 0.36 & $75 \%$ & $88.9 \%$ & 34.5 & $\begin{array}{l}\text { Function statistically } \\
\text { at } 0.01\end{array}$ \\
\hline \begin{tabular}{l} 
Total grade \\
\hline
\end{tabular} & 4.4 & 0.39 & $75 \%$ & $\begin{array}{l}\text { Function statistically } \\
\text { at } 0.01\end{array}$ \\
\hline
\end{tabular}

It is clear from the Table 2 above that significant differences exist in the average grades of the student teachers (sample study), based on the e-portfolio assessment cards for the best work checklist and selected value (75\%), as all the relative weights of the actual mean are above the percentage for the default. This is due to the students' awareness of the criteria that will be evaluated, based on a list of their best work. The portfolio explains the reason for choosing the best work, links its importance to evidence, and ponders the work and criticisms of its conclusions written in the correct language.

Table 3. T-test for one group to compare the average student teachers' scores (sample)

E-portfolio score card showing strengths and weaknesses (checklist and selected value: 75\%)

\begin{tabular}{|l|c|c|c|c|c|c|}
\hline Checks & $\begin{array}{l}\text { Arithmetic } \\
\text { mean }\end{array}$ & $\begin{array}{l}\text { Standard } \\
\text { deviation } \\
\text { (default) }\end{array}$ & $\begin{array}{l}\text { average percentage } \\
\text { average percentage } \\
\text { actual) }\end{array}$ & T value & Significance level \\
\hline $\begin{array}{l}\text { Field of } \\
\text { planning }\end{array}$ & 4.7 & 0.13 & $75 \%$ & $70 \%$ & 35.3 & $\begin{array}{l}\text { Function statistically } \\
\text { at } 0.01\end{array}$ \\
\hline $\begin{array}{l}\text { Scope of } \\
\text { classroom } \\
\text { management }\end{array}$ & 3.8 & 0.82 & $75 \%$ & $77 \%$ & 52.6 & $\begin{array}{l}\text { Function statistically } \\
\text { at } 0.01 \\
\text { at } 0.01\end{array}$ \\
\hline $\begin{array}{l}\text { Scope of use of } \\
\text { teaching } \\
\text { methods }\end{array}$ & 3.9 & 0.91 & $75 \%$ & $80.3 \%$ & 48.91 & $\begin{array}{l}\text { Function statistically } \\
\text { at } 0.01\end{array}$ \\
\hline $\begin{array}{l}\text { Scope of use } \\
\text { of teaching aids }\end{array}$ & 4.5 & 0.64 & $75 \%$ & $80 \%$ & 52.5 & $\begin{array}{l}\text { Function statistically } \\
\text { at } 0.01\end{array}$ \\
\hline $\begin{array}{l}\text { Scope of } \\
\text { evaluation }\end{array}$ & 3.8 & 0.46 & $75 \%$ & $79.3 \%$ & 58.5 & $\begin{array}{l}\text { Function statistically } \\
\text { at } 0.01\end{array}$ \\
\hline \begin{tabular}{l} 
Total grade \\
\hline
\end{tabular} & 4.3 & 0.41 & $75 \%$ & & & $57 \%$ \\
\hline
\end{tabular}

It is clear from the Table 3 above that significant differences exist in regard to the average grades of the student teachers (sample study) based on the e-portfolio assessment cards, which include the strength and weakness checklist, and all the relative weights of the actual mean are above the default percentage of $75 \%$. This is due to self-feedback on some contents of the e-portfolios prepared by the student teachers: video clips, audio recordings, and peer feedback. This helped the researcher to identify weaknesses in order for these areas to be improved, as well as strengths to be furthered strengthened. 
ENTREPRENEURSHIP AND SUSTAINABILITY ISSUES

ISSN 2345-0282 (online) http://jssidoi.org/jesi/

2019 Volume 6 Number 4 (June)

http://doi.org/10.9770/jesi.2019.6.4(12)

Table 4. T-test for one group to compare the average student teachers' scores (sample)

E-portfolio score cards containing strengths and weaknesses (checklist and selected value: 75\%)

\begin{tabular}{|l|c|c|c|c|c|l|}
\hline Checks & $\begin{array}{l}\text { Arithmetic } \\
\text { mean }\end{array}$ & $\begin{array}{l}\text { Standard } \\
\text { deviation } \\
\text { (default) }\end{array}$ & $\begin{array}{l}\text { average percentage } \\
\text { average percentage } \\
\text { actual) }\end{array}$ & $\begin{array}{l}\text { T value } \\
\text { level }\end{array}$ \\
\hline $\begin{array}{l}\text { teaching } \\
\text { experiences }\end{array}$ & 4.3 & 0.33 & $75 \%$ & $85.6 \%$ & 35.3 & $\begin{array}{l}\text { Function statistically } \\
\text { at } 0.01\end{array}$ \\
\hline Best work & 4.8 & 0.72 & $75 \%$ & $89.8 \%$ & 65 & $\begin{array}{l}\text { Function statistically } \\
\text { at } 0.01\end{array}$ \\
\hline $\begin{array}{l}\text { Strengths and } \\
\text { weaknesses }\end{array}$ & 3.9 & 0.26 & $75 \%$ & $79.5 \%$ & 52.5 & $\begin{array}{l}\text { Function statistically } \\
\text { at } 0.01\end{array}$ \\
\hline Total grade & 4.3 & 0.39 & $75 \%$ & $84.3 \%$ & 58.5 & $\begin{array}{l}\text { Function statistically } \\
\text { at } 0.01\end{array}$ \\
\hline
\end{tabular}

It is clear from the Table 4 above that there are significant differences in the average grades of student teachers (study sample), based on the e-portfolio score cards and the selected value (75\%). All the relative weights of the actual average are above the percentage of the default mean. The access of the study group members to their ability to achieve this level of proficiency (75\%) can be explained by the student teachers' awareness of the parameters of the e-portfolios, their importance, the steps involved in their preparation, and the standards that will be evaluated. This is in addition to the feedback they received from the researcher and her peers while they viewed the file. Some examples of e-portfolios were presented and discussed with the student teachers. A determination about the objectives was made in terms of the achievements of the e-portfolios containing the compilation of experiences and the selection of the best work. The aim was to identify strengths and weaknesses and to present the files in front of their peers, as this helped to increase their self-confidence, as well as competition among themselves. It also helped the researcher to clarify how to deal with photos, video recordings, and audio recordings using simple technology, such as cellular phones, as well as some of the multimedia programs that students used to make their files attractive.

The results of the present study are consistent with those obtained by Dessouki (2010) and Ismail (2005), whose research concluded thate-portfolios are an exciting and easy-to-use technical tool that is more usable than its traditional counterpart. E-portfolios can be used in various courses. In addition there is the possibility of eportfolios being used by faculty members as teaching files.

\section{Results of the third question}

"What is the effect of the use of e-portfolios on the development of professional standards for student teachers in the College of Education at Princess Noura Bint Abdul Rahman University?" To answer this question, the researcher used the ( $\eta 2)$ ETA square and (d) value, which reflect the magnitude of the impact of the differences between the pre -and post-application development of teaching competencies (Table 5):

Table 5. Suggested reference table for determining the volume of impact levels for each measure of impact size

\begin{tabular}{|c|c|c|c|}
\hline \multirow{2}{*}{ Tool used } & \multicolumn{3}{|c|}{ Effect size } \\
\cline { 2 - 4 } & small & Medium & Large \\
\hline$\eta 2$ & 0.02 & 0.07 & 0.17 \\
\hline $\mathrm{d}$ & 0.3 & 0.4 & 0.7 \\
\hline
\end{tabular}


ENTREPRENEURSHIP AND SUSTAINABILITY ISSUES

ISSN 2345-0282 (online) http://jssidoi.org/jesi/

2019 Volume 6 Number 4 (June)

http://doi.org/10.9770/jesi.2019.6.4(12)

Table 6. The magnitude of the effect of the differences between the dvalue and the significance level, the ETA value, the t-value, the value of the t-test, and the post-application teaching competencies

\begin{tabular}{|l|c|c|c|c|}
\hline Checks & t-value & $(\eta)$ Value & $\mathrm{d}$-value & effect size \\
\hline $\begin{array}{l}\text { Field of } \\
\text { planning }\end{array}$ & 143.3 & 0.99 & 38.3 & significant \\
\hline $\begin{array}{l}\text { Scope of } \\
\text { classroom } \\
\text { management }\end{array}$ & 102.2 & 0.99 & 26.4 & significant \\
\hline $\begin{array}{l}\text { Scope of use of } \\
\text { teaching } \\
\text { methods }\end{array}$ & 80.3 & 0.99 & 17.6 & significant \\
\hline $\begin{array}{l}\text { Scope of use } \\
\text { of teaching aids }\end{array}$ & 61.5 & 0.99 & 16.91 & significant \\
\hline $\begin{array}{l}\text { Scope of } \\
\text { evaluation }\end{array}$ & 65.8 & 0.99 & 18.5 & significant \\
\hline Total grade & 125.3 & 0.99 & 32.5 & \\
\hline
\end{tabular}

The Table 6 above shows that the impact sizes of the independent variable (e-portfolios) is greater than 0.8 , thereby indicating that the $\mathrm{d}$ of the dependent variable (professional standards) is significant. This is because the use of e-portfolios has a significant impact on the development of professional standards among the student teachers based on the sample's study parameters.

The e-portfolios, which contain lesson plans, audio recordings, video recordings, and multiple other contents, provide a rich environment for self-evaluation through meditation. This, in turn, provides valuable opportunities for students to think about their lessons and decide whether their teaching objectives have been achieved. This reflection serves as a framework for the student's self-assessment in addition to enabling peer assessment in the form of feedback received by the student teacher from his or her colleagues in the viewing classes. They are able to discuss their experiences via the Internet, as well as the diverse sources of information.

The Internet enables the use of printed (e.g., books and magazines) and other materials (e.g., tapes and films) obtained from different educational sites and multiple sources. The student teacher is able to collect some of the contents of the e-portfolios, such as, information about how to enrich the class environment, the appropriate teaching methods, experience in the field of classroom management, and so on. One of the many features is the sheer volume of information, which enables the provision and review of numerous and diverse educational ideas and modern pedagogical methods that lead to a reduction in effort, time, and cost.

\section{Results of the fourth question}

"What is the effect of using e-portfolios on the life skills development of student teachers in the College of Education at Princess Noura Bint Abdul Rahman University?'To answer this question, the researcher used ( $\eta 2$ ) ETA square and the (d) value, which both reflect the magnitude of the impact of the differences between the pre and post-application development of certain life skills (Table 7).

Table 7. Suggested reference table for determining the volume of the impact levels for each measure of impact size

\begin{tabular}{|c|c|c|c|}
\hline \multirow{2}{*}{ Tool used } & \multicolumn{2}{|c|}{ Effect size } & Large \\
\cline { 2 - 4 } & small & medium & 0.18 \\
\hline$\eta 2$ & 0.03 & 0.08 & 0.6 \\
\hline
\end{tabular}




\section{ENTREPRENEURSHIP AND SUSTAINABILITY ISSUES}

ISSN 2345-0282 (online) http://jssidoi.org/jesi/

2019 Volume 6 Number 4 (June)

http://doi.org/10.9770/jesi.2019.6.4(12)

Table 8. The magnitude of the effect of the differences between the application and the significance level, the ETA value, the value of the t-test, and the post-application life skills of student teachers

\begin{tabular}{|l|c|c|c|c|}
\hline Skill & t-test & $(\eta)$ value & D-value & effect size \\
\hline Interpersonal communication & 141.6 & 0.99 & 36.3 & significant \\
\hline Decision-making & 104.2 & 0.99 & 23.4 & significant \\
\hline Problem-solving & 78.3 & 0.99 & 15.6 & significant \\
\hline Academic & 71.5 & 0.99 & 14.91 & significant \\
\hline Total & 130.3 & 0.99 & 34.5 & significant \\
\hline
\end{tabular}

The Table 8 above shows that the impact size of the independent variable (e-portfolios) is greater than 0.8 , thereby indicating that (d) of the dependent variable (life skills) is significant. This is because the use value of the e-portfolios has a significant impact on the development of life skills among student teachers based on the sample's study parameters.

The results showed the impact of the quality of student teachers' life skills that lead to the development of their academic achievements. The acquisition of life skills encourages them to engage in scientific research and discovery, which are directly related to the lives of the students and the people in their communities. It also increases their cognitive output and the depth and breadth of their knowledge of concepts acquired from previous lessons. As a result, in-depth reflection and discussion of ideas contribute to their strong desire to address issues by examining them from several points of view that lie outside of traditional-thinking frameworks.

\section{Results of the fifth question}

"Are there any statistically significant differences between the average pre- and post-application student teachers in the College of Education at Princess Noura Bint Abdul Rahman University based on the checklist of professional standards?'To answer this question, the researcher used a t-test for two related groups to compare the average grades of student teachers based on the checklist of professional standards for student teachers between the pre- and post-tribal applications, as shown in the following table (Table 9):

Table 9. The mean, standard deviation, t-test, and significance level of group members in the pre- and post-application stages in terms of the professional standards of the student teachers

\begin{tabular}{|c|c|c|c|c|c|}
\hline Areas & Application & $\begin{array}{l}\text { Arithme- } \\
\text { tic mean }\end{array}$ & $\begin{array}{l}\text { Standard } \\
\text { deviation }\end{array}$ & $\begin{array}{c}\text { Value of } \\
\mathrm{T} \\
\end{array}$ & Level of significance \\
\hline \multirow[t]{2}{*}{ Field of planning } & pre & 2.3 & 0.18 & \multirow[t]{2}{*}{143.16} & \multirow[t]{2}{*}{ Function statistically at 0.01} \\
\hline & post & 4.8 & 0.19 & & \\
\hline \multirow{2}{*}{$\begin{array}{l}\text { Scope of classroom } \\
\text { management }\end{array}$} & pre & 2.1 & 0.31 & \multirow[t]{2}{*}{101.29} & \multirow[t]{2}{*}{ Function statistically at 0.01} \\
\hline & post & 4.5 & 0.29 & & \\
\hline \multirow{2}{*}{$\begin{array}{l}\text { Scope of use of } \\
\text { teaching methods }\end{array}$} & pre & 2.4 & 0.30 & \multirow[t]{2}{*}{68.18} & \multirow[t]{2}{*}{ Function statistically at 0.01} \\
\hline & post & 4.9 & 0.29 & & \\
\hline \multirow{2}{*}{$\begin{array}{l}\text { Scope of use of } \\
\text { teaching aids }\end{array}$} & pre & 2.2 & 0.29 & \multirow[t]{2}{*}{64.13} & \multirow[t]{2}{*}{ Function statistically at 0.01} \\
\hline & post & 4.7 & 0.30 & & \\
\hline \multirow[t]{2}{*}{ Scope of evaluation } & pre & 2.5 & 0.18 & \multirow[t]{2}{*}{63.63} & \multirow[t]{2}{*}{ Function statistically at 0.01} \\
\hline & post & 4.9 & 0.19 & & \\
\hline \multirow[t]{2}{*}{ Total grade } & pre & 2.2 & 0.17 & \multirow[t]{2}{*}{125.01} & \multirow[t]{2}{*}{ Function statistically at 0.01} \\
\hline & post & 4.7 & 0.16 & & \\
\hline
\end{tabular}

From the previous table it can be seen that there are differences in the mean scores of student teachers, based on the checklist of the professional standards of student teachers in the College of Education at Princess Noura Bint Abdul Rahman University, between the pre- and post-application stages in all fields, and the overall scores of the scale favor the post-application stage. Additionally, the results of this study are consistent with those of Dessouki 


\section{ENTREPRENEURSHIP AND SUSTAINABILITY ISSUES}

ISSN 2345-0282 (online) http://jssidoi.org/jesi/

2019 Volume 6 Number 4 (June)

http://doi.org/10.9770/jesi.2019.6.4(12)

(2010), Saqr (2006), Al-Ahmad (2003), and Bakkar et al. (2003), which concluded that e-portfolios facilitate the professional growth of student teachers by enabling them to contemplate their practice. Student teachers have greater opportunities to meditate and reflect on their experiences.

\section{Results of the sixth question}

"Are there any statistically significant differences between the average pre- and post-application student teachers in the College of Education at Princess Noura Bint Abdul Rahman University in terms of the life skills scale?'To answer this question, the researcher used a t-test for two related groups to compare the average grades of student teachers on the life skills scale between the pre- and post-tribal applications, as shown in the following table (Table 1):

Table 10. The mean, SD, t-test, and significance level of group members related to the life skills of student teachers in their pre- and postapplication stages

\begin{tabular}{|c|c|c|c|c|c|}
\hline Skills & Application & $\begin{array}{l}\text { Arithme- } \\
\text { tic mean }\end{array}$ & $\begin{array}{l}\text { Standard } \\
\text { deviation }\end{array}$ & $\begin{array}{c}\text { Value of } \\
\mathrm{T}\end{array}$ & Level of significance \\
\hline \multirow[t]{2}{*}{ Interpersonal } & pre & 2.1 & 0.17 & \multirow[t]{2}{*}{141.26} & \multirow[t]{2}{*}{ Function statistically at 0.01} \\
\hline & post & 4.9 & 0.18 & & \\
\hline \multirow[t]{2}{*}{ Decision-making } & pre & 2.2 & 0.30 & \multirow[t]{2}{*}{104.21} & \multirow[t]{2}{*}{ Function statistically at 0.01} \\
\hline & post & 4.9 & 0.28 & & \\
\hline \multirow[t]{2}{*}{ Problem-solving } & pre & 2.1 & 0.31 & \multirow[t]{2}{*}{65.14} & \multirow[t]{2}{*}{ Function statistically at 0.01} \\
\hline & post & 4.8 & 0.27 & & \\
\hline \multirow[t]{2}{*}{ Academic } & pre & 2.1 & 0.28 & \multirow[t]{2}{*}{62.23} & \multirow[t]{2}{*}{ Function statistically at 0.01} \\
\hline & post & 4.8 & 0.31 & & \\
\hline \multirow[t]{2}{*}{ Total } & pre & 2.1 & 0.16 & \multirow[t]{2}{*}{128.01} & \multirow[t]{2}{*}{ Function statistically at0.01 } \\
\hline & post & 4.8 & 0.18 & & \\
\hline
\end{tabular}

The table shows that with regard to the life skills scale, there are differences in the mean score of the student teachers at the College of Education at Princess Noura Bint Abdul Rahman University between the pre- and postapplication stages in all fields, and the overall score of the scale favors the post-application stage.

This finding can be attributed to the fact that the use of e-portfolios that are based of life skills has helped student teachers to interact effectively, ask questions, and benefit from their previous knowledge and experiences, which link them to new knowledge and current information. This results in the expansion of student teachers' experience and the generation of new, in-depth information, which is further enhanced by the collection of concepts and knowledge to be derived from field training. It increases their motivation to learn, and helps them to interact to promote knowledge and new realities. It also encourages dialogue about the issues that are at the core of teaching, provides the opportunity for all students to participate actively in the learning process, and causes cognitive structures to be more coordinated and organized, thereby contributing to an increase in academic achievement.

Wafi (2010) confirmed the effectiveness of the Life Skills Education Program in improving the concept of selflearning, and this is in line with the findings of Papacharisis, Goudas, Theodorakis, and Danish (2005). These studies underscore the importance of methods that are based on the use of positive reinforcement, collective participation, dialogue, debate, modeling, feedback, and role playing in the development of students' life skills, such as positive thinking, personal responsibility, and academic achievement. This emphasizes the superiority of teaching that is based on life skills over traditional methods of education in the development of educational attainment. 


\section{ENTREPRENEURSHIP AND SUSTAINABILITY ISSUES}

ISSN 2345-0282 (online) http://jssidoi.org/jesi/

2019 Volume 6 Number 4 (June)

http://doi.org/10.9770/jesi.2019.6.4(12)

\section{Conclusions}

The findings of this study reveal that the use of e-portfolios improves capabilities, skills, and knowledge. It encourages student teachers to know about tendencies, trends, and interests by preparing thefile and making the effort to compile its contents. It also ensures that it is well presented so that it can be used tochannel learning in the appropriate direction - that is, in keeping with the students'abilities and tendencies - to enable productivity.

E-portfolios reveal the strengths and weaknesses of student teachers. It can help them to avoid their weaknesses, enhance their strengths, and contribute to the appropriate programs that prepare student teachers. This would enable them to improve and develop these programs based on the data that are collected through the student teachers' e-portfolios. This saves time and effort and is more orderly than the use of paper files. E-portfolios help the students identify the results of their progress and give them clear ideas about their performance through the comments received from their educational supervisors, teaching colleagues, and/or peers. This feedback gives them a clear idea of their deficiencies and how to improve their performance. In addition, it enables the exchange of diverse experiences through the Internet.

The use ofe-portfolios contributes significantly to motivating student teachers through the handling of multimedia programs used to display the contents of their e-portfolios in an organized way. It also helps them to use the Internet to send emails, receive comments, and search for new information and knowledge. This gives them a clear vision of the most important developments related to the field of education. E-portfolio use also allows student teachers to work more efficiently, especially in regard to structural assessments, due to the possibility of modifying the contents of the file.

E-portfolios provide real-life opportunities for student teachers to engage inself-learning by undertaking selfdirected activities, which include tasks such as solving problems, making decisions, and cooperating with others. These tasks increase theirmotivation to learn, which contributes to the long-term improvement of their selfconcept. They benefit from these improved attitudes toeducation in their future lives. This also enhances their independence, encourages them to take responsibility for their learning, and increasestheir interest in learning and their willingness to confront educational situations. It also contributes to the development of their tendencies to satisfy their needs and refine their talents, which, in turn, helps to raise the performance level and skills of student teachers.

Finally, e-portfolios contribute to the diversity of content, as they combine learning processes and evaluations through an in-depth understanding of the work (contemplative thinking) andthe provision of appropriate feedback. Using e-portfolios causes the role of traditional student teachers to change, as the student teacher becomes an inventor who searches for information and knowledge by reviewing different sources, such as libraries and the Internet, as well as teachers and supervisors. They also attend conferences and seminars. These actions allow students to expand their horizons to coincide with the latest developments of this era. Additionally, the use of eportfolios contributes significantly to the change from a traditional to an electronic environment in the educational process. It is expected that the findings of the study will be of great importance to educators and student teachers in their quest for excellence. 


\section{ENTREPRENEURSHIP AND SUSTAINABILITY ISSUES}

ISSN 2345-0282 (online) http://jssidoi.org/jesi/

2019 Volume 6 Number 4 (June)

http://doi.org/10.9770/jesi.2019.6.4(12)

\section{References}

Abdullah, A. (2007). Teaching competencies for teachers in secondary schools in Medina Aden from the point of view of the teachers themselves. Journal of Educational Studies and Research, 9, 208-22.

Abdul-Samie, M., Hawala, S. (2005). Teacher Preparation. Amman, Jordan: Dar Al Fikr.

AbuSwain, R. (2010). Educational Qualifications for Teachers Students A classroom teacher at the Faculty of Education at Al-Azhar University, from their point of view, in the light of their training needs. Islamic University Journal, Series of Humanities Studies, $18,2-38$.

Aga, H. (2012). Using the files of achievement and collaborative learning in developing the skills of expressionCreative writing for $10^{\text {th }}$ grade students in Palestine. Unpublished PhD thesis Mansoura, Egypt, Ain Shams University: Faculty of Education.

$\mathrm{Al}$ - Omari, J. (2013). The extent to which Jordanian university students are aware of life skills In light of the knowledge economy. Journal of Psychological and Educational Studies, 10.

Al Masad, A. (2012). Learners' perceptions of the E-portfolios in learning and evaluation. Studies in University Education - Egypt, p. 2344.

Al-Khamisi, S. (2003). The attitude of the student teachers about the effectiveness of supervising educationOperation in the Middle Colleges of Teachers and Teachers in the Sultanate of Oman .Egypt-Alexandria: Dar El Wafaa Printing \& Publishing.

Andreson, R.S. \& DeMuelle, L. (1998). Portfolio use in twenty four teacher education programs, Teacher Education Quartely, 25, 23-31

Ayad, F. \& Saaduddin, H. (2010). The effectiveness of a proposed scenario for including some life skills in the technology course for the tenth grade in Palestine. Al-Aqsa University Journal, Human Sciences Series, 1(14).

Barrett, H. C. (2007). Research Electronic Portfolios and learner engagement: The REFLECT Initiative, Journal of Adolescent and Adult Literacy, 50(6), 436-449.

Buckley, S., Coleman, J., \& Khan, K. (2010). Best evidence on the educational effects of undergraduate portfolios. Clinical Teacher, 7(3), 187-191. http://doi.org/10.1111/j.1743-498X.2010.00364.X

Chatham, A., Seawel, L., \&Raschig, J. (2009). Avoiding the pitfalls: Current practices and recommendations for ePortfolios in higher education. Journal of Educational Technology Systems, 38(4), 437-456. http://doi.org/10.2190/ET.38.4.e

Chau, Y., Cheng, M. (2010). EFL Instruction and assessment with portfolio: ACase study in Tawin. National Chung Cheng University, Taiwan.

Constantine, H. \& Lorenz, M. (2004). Professional Achievement Profile, Distinguished Teacher's Guide, Palestine: University Book House.

Dahlan, O. (2010). Teacher in Education and Learning. Palestine, Gaza: Afaq Library.

Danish, H. \& Steven, V. (2000). New Roles for Sports Psychologists: Teaching Life Skills Through Sport to At- Risk Youth. Quest Human Kinetics, 49(1), 100 - 14.

Deneen, C., \& Shroff, R. (2010). E-Portfolio use in two institutes of higher education: Acomparative case study. Proceedings of the European Conference on eLearning, 92-100.

Dietrich, J. W., \& Olson, C. (2010). In quest of meaningful assessment of international learning: The development and implementation of a student survey and e-Portfolio approach. JGE: The Journal of General Education, 59(3), 143-158.

Fatalawi, S. (2003). Teaching competencies: Concept - Training - Performance. Jordan: Dar Al Shorouk.

Fenwick, T., \& Parsons, J. (2009). The art of evaluation. Toronto: Thompson Educational Publishing.

Gartner, I. (2011). Hype Cycle Research Methodology, Retrieved from http://www.gartner.com/technology/research/methodologies/hypecycle.jsp

Gordon, M. (2009). Toward a Pragmatic Discourse of Constructivism, Reflections on Lessons from Practice, Journal of Teacher Education, 24(1), 17-20

Granberg, C. (2010). E-portfolios in teacher education 2002-2009: The socialconstruction of discourse, design and dissemination. European Journal of Teacher Education, 33(3), 309-322. http://doi.org/10.1080/02619761003767882 


\section{ENTREPRENEURSHIP AND SUSTAINABILITY ISSUES}

ISSN 2345-0282 (online) http://jssidoi.org/jesi/

2019 Volume 6 Number 4 (June)

http://doi.org/10.9770/jesi.2019.6.4(12)

Greene, H. A. (2008). Learn from Yesterday, Live for Today, Hope for Tomorrow: The Development of A life Skills Scale. Oxford, OHIO, Miami University. Available online at: http://rave.ohiolink.edu/etdc/view?acc\%5Fnum=miami1213282018

Hallam, G., \& Creagh, T. (2010). E-Portfolio use by university students in Australia: A review of the Australian e-Portfolio Project. Higher Education Research \& Development, 29(2), 179-193. http://doi.org/10.1080/07294360903510582

Hassan, A. (2009). The Effect of Teaching on the Model of Witley on the Achievement of Sixth Grade Students in Science and the Development of Their Attitudes towards them. Egyptian Association for Curriculum and Teaching Methods, Faculty of Education, Ain Shams University, No. 137.

Holt, N. L and others (2008). Do Youth Learn Life Skill through TheirInvolvement in High School Sport? A Case Study, Canadian Journal of Education, 31(2), 281-304 http://www.csse.ca/CJE/General.hthttp://www.omanls.cnet/

Jamea, H. (1984) Teaching competenciesFor the primary school teacher in the State of Kuwait. Educational Journal, 1(2).

Lowendahl, J.-M. (2011). Hype Cycle for Higher Education, 2011. Retrieved from http://www.gartner.com/DisplayDocument?id=1755718\&ref='g_fromdoc'

Makhlafi, A. (2004) The Impact of Community Assessment and Feedback on the Development of Educational Efficiency in Female Teachers in Taiz University, Research and Educational Studies, p. 2, Yemen: Taiz University: Faculty of Education.

Mazen, H. (2009). Practical Education to employ IT skills in the design, preparation and use of E-portfolios, Journal of the Egyptian Association for Practical Education, Special issue The thirteenth scientific conference (2-4).

Mulla, F. (2004). The Effectiveness of Using the Micro Teaching Method in the Development of Some Instructional Competencies of Teaching Students at the Department of Physical Education, University of Bahrain. Educational Journal, 18, 72.

Papacharisis, V., Goudas, M., Theodorakis, Y and Danish, S. J. (2005). The Effectiveness of Teaching a Life Skills Program in a Sport Context, Journal of Applied Sport Psychology, 17, 247-254. http://doi.org/10.1080/10413200591010139

Paulson, F., Paulson, P., and Meyer, C. (1991). What Makes a Portfolio?, Educational Leadership, 48(5), 60-63.

Qutait, G. (2009). Computerization of the classroom calendar, Amman: House of Culture.

Sulphey, M. M. \& Al Kahtani, N. S. (2017). Economic security and sustainability through social entrepreneurship: the current Saudi scenario, Journal of Security and Sustainability Issues 6 (3), 479-490. http://dx.doi.org/10.9770/jssi.2017.6.3(12)

Sulphey, M. M. \& Al-Kahtani, N. S. (2018). Academic Excellence of Business Graduates through Nudging: Prospects in Saudi Arabia, International Journal of Innovation and Learning, 24(1), 98-114. http://doi:10.1504/IJIL.2018.10013022

Sulphey, M. M. (2017). Game based learning as an aid for extenuating Higher Education Sector issues - The case of Saudi Arabia. International Journal of Simulation, Systems, Science and Technology, 18 (1), 6.1-6.10. https://doi.org/10.5013/IJSSST.a.18.01.06

Sulphey, M. M., AlKahtani, N. S. \& Syed, A. M. (2018). Relationship between Admission Grades and Academic Achievement, Entrepreneurship and Sustainability Issues, 5(3) http://doi.org/10.9770/jesi.2018.5.3(17)

Tindall-Ford, S., Waters, K., \& Johnson, N. F. (2010). An evaluation of a web-based e-portfolio system in an Australian pre-service teacher education program. International Journal of Learning, 17(4), 297-308.

Tkacova, A., Kubak, M., Androniceanu, A., Tvaronavičienė, M., Huculova, E. (2018). Financial literacy of students in chosen universities - research platform for regulatory processes of educational system in Slovakia, E + M. Economics and Management 21(1): 175-190 https://doi.org/10.15240/tul/001/2018-1-012

Winsor, P., Burr, R., \& Reeves, H. (1999). Portraying Professional Development in Preservice Teacher Education: Can portfolios do the job? Journal of Teachers and Teaching: Theory and Practice, 5(1), 9-30. http://dx.doi.org/10.1080/1354060990050102

Young, D. and Young, D. (1969). The Effectiveness of individually Prescribed Micro Teaching Module on An intern subsequent classroom performance. Paper Presented at the annual Meeting of American Educational Research Association. 


\section{ENTREPRENEURSHIP AND SUSTAINABILITY ISSUES}

ISSN 2345-0282 (online) http://jssidoi.org/jesi/

2019 Volume 6 Number 4 (June)

http://doi.org/10.9770/jesi.2019.6.4(12)

Short biographical note about the contributors at the end of the article (name, surname, academic title and scientific degree, duties, research interests):

Dr. Maha Mohammed ALAJMI is Professor, Curriculum \& Instruction Department, College of Education, Princess Nourah Bint Abdulrahman University, Riyadh, Saudi Arabia. She is passionate about teacher education, and has done many resesches in this are which has been pblised in reputed journals. She is serving as Chairperson and member in various important committees in the University.

ORCID ID: https://orcid.org/0000-0001-6387-3229

Copyright (C) 2019 by author(s) and VsI Entrepreneurship and Sustainability Center

This work is licensed under the Creative Commons Attribution International License (CC BY).

http://creativecommons.org/licenses/by/4.0/

(c) (†) Open Access 